\title{
Analytical Assessment of Borehole Water in Some Local Government Areas of Akwa Ibom State, South-South Nigeria
}

\author{
Edet W. Nsi, \\ Emaime J. Uwanta, \\ Aniekan E. Akpakpan, \\ Ifiok O. Ekwere, \\ Akwa Ibom State University, Ikot Akpaden, Nigeria
}

Department of Chemistry, Faculty of Physical Sciences,

Doi:10.19044/esj.2020.v16n12p122 URL:http://dx.doi.org/10.19044/esj.2020.v16n12p122

\begin{abstract}
In this study, analytical assessment of borehole water was carried out in selected non-oil producing Local Goverment Areas of Akwa Ibom State, Nigeria. The areas were Uyo, Itu, and Ibesikpo Asutan Local Government Areas. The sampling areas were divided into three (3) zones with nine (9) sampling sites. For Itu L.G.A., the sampling site were,Urua Ekpa (BW1), Akon Itam (BW2) and Nung Ukot Itam (BW3); Uyo L.G.A., the sampling sites were Oron road, (BW4), Ekpri Nsukara (BW5), Obio Offot (BW6); the sampling sites in Ibesikpo L.G.A. were Ikot Akpanabia (BW7), Ikot Atang (BW8), Mbikpong (BW9). A total of nine water samples, obtained from boreholes in the study areas, were analyzed for their physico-chemical parameters such as $\mathrm{pH}$, temperature, salinity, conductivity, total dissolved oxygen, dissolved oxygen, biochemical oxygen demand, chemical oxygen demand, alkalinity, acidity and total dissolved solid. Anions determined were phosphates $\left(\mathrm{PO}_{4}{ }^{3-}\right)$, nitrates $\left(\mathrm{NO}_{3}{ }^{-}\right)$, chlorides $\left(\mathrm{Cl}^{-}\right)$, sulphates $\left(\mathrm{SO}_{4}{ }^{2-}\right)$ while cations analysed were $\mathrm{Mg}^{2+}, \mathrm{Cd}^{2+}, \mathrm{Fe}^{2+}, \mathrm{Ni}^{2+}$ and $\mathrm{Pb}^{2+}$. The results obtained reveal that the amounts of all the heavy metals determined in all the water samples were within the WHO acceptable standard for drinking water, with the exception of iron. It was also observed that the anions concentrations were below the WHO acceptable standard for drinking water. The high concentrations of cations in the analyzed ground water can largely be attributed to anthropogenic sources. In conclusion, the physico-chemical properties, as well as the concentrations of cations and anions in the under ground water usually affect the overall water quality, hence highlighting the need for frequent monitoring.
\end{abstract}


Keywords: Borehole Water, Physicochemical Parameters, Cations, Anions And Heavy Metal

\section{Introduction}

Water is essential for the survival of human beings, livestock and other living organisms. In Africa and some other developing countries, availability of safe drinking water is a sustainability issue. Water sources available to most developing countries are rivers, natural ponds, and rainfall. In few areas, there are underground water supplies through boreholes and water distribution tankers (Pawari and Gawande, 2015). A unique characteristic of the earth, in comparison with other planets, is the presence of water, covering about $75 \%$ of the earth surface (Pawari and Gawande, 2015).

Water is basically classified into surface water and ground water. Surface water refers to rivers, streams, lakes, oceans, ponds and wetland while ground water is present below the earth's surface where it is stored in porous soils and rocks (Madden, 1995). Water is very essential for purposes like drinking, power generation, food processing, etc; thus, it is necessary to ensure that water is adequate both in quality and quantity (Meador, 1995).Water pollution is generally caused by the introduction of waste or toxic materials into the environment by nature or by anthropogenic activities. Considering the different segment of the environment (land, air and water), water pollution is significant because it affects the entire ecosystem; thus, the quality of water that is available for utilization is of essence (Goel, 1995; Arjun, et al., 2015).

Globally, water quality is threatened by numerous sources of pollution such as sewage and domestic waste, industrial effluents, agricultural discharge, fertilizers, toxic metals, detergents etc. (Bashir and Olalekan, 2012; Raphael, 2016; Khitoliya, 2004). Underground water can also be containated by micro-organisms (Ebrahim et al., 2014). The presence of pollutants in water leads to a range of deleterious effects on the ecosystem; for instance, human exposure to high level of heavy metals in water can cause several health problems such as blood disorder, kidney damage and neurological damage (Gloria and Token, 2015).

Therefore, researches on measures aimed at protecting or improving water quality will consequently breed ecofriendly situations for man and the entire ecosystem (Istifanus et al., 2013). Accordingly, the aim of this study is to evaluate the physicochemical parameters and possible contamination level of toxic elements in borehole water in some non oil producing local government areas of Akwa Ibom State, Nigeria. 


\section{Materials and Methods \\ Study Area}

Akwa Ibom State is one of the oil producing States in Niger Delta Region of Nigeria. It has 31 local government areas with Uyo, Eket, Ikot Ekpene, Abak, Etinan, and Oron being the most developed urban center. According to the National Population Census NPC., (2007), the state has a total human population of $3,920,208$, with $87.89 \%$ resident in the rural areas while $12.11 \%$ of the population lives in the urban area.The study area has a population of 152,208, 222,841, and 140,916 for Ibesikpo, Uyo, and Itu Local Government Areas, respectively. Geographically, it lies between latitudes 4 $32^{\circ} \mathrm{N}$ and $532^{\circ} \mathrm{N}$ and longitude $928^{\circ} \mathrm{E}$ and $825^{\circ} \mathrm{E}$ and $825^{\circ} \mathrm{E}$ (NPC., 2007). Akwa Ibom State has total land area $6,187 \mathrm{~km}^{2}$, which represents about $0.67 \%$ of the total land mass of Nigeria (Jacob and Peter, 2015).

\section{Sampling and sampling technique}

Water samples were collected using white polyethylene bottles (1L) from three sampling locations in each Local Government Areas. Prior to samples collection, the bottles were properly washed and rinsed several times, with warm water first and then with distilled water. Hydrochloric acid and boric acid were used as preservatives in the sampling bottles for trace elements and nitrate respectively before going to field. Sampling bottles were used directly by holding the bottles vertically and the water was allowed to flow in gently, leaving sufficient air space in the bottles (except those for DO determination) to allow for expansion of the water at increased temperature. Water samples for DO and BOD were collected in brown glass bottles, which were carefully filled without trapping air bubbles. Samplebottles were labeled accurately for identification and preserved in the laboratory refrigerator at $4^{\circ} \mathrm{C}$. The concentration ofanions $\left(\mathrm{PO}_{4}{ }^{3-}, \mathrm{NO}_{3}{ }^{-}, \mathrm{Cl}^{-}, \mathrm{SO}_{4}{ }^{2-}\right)$ and heavy metals $\left(\mathrm{Fe}^{2+}, \mathrm{Ni}^{2+}, \mathrm{Pb}^{2+}, \mathrm{Cd}^{2+},\right)$ were determinedusing the (Unicam939/959) Spectrometer and Atomic Absorption Spectrophotometer respectively.

\section{Physicochemical Parameters}

In this study, the physico-chemical parameters determined include; electrical conductivity (EC), $\mathrm{pH}$, temperature, acidity, alkalinity, total dissolved solids (TDS), total suspended solids (TSS), biochemical oxygen demand (BOD), chemical oxygen demand (COD) anddissolved oxygen

\section{pH Determination}

A pH meter model 3320 JENWAY(electronic)was initially standardized using buffer solution (4 and 9). The electrode was rinsed with distilled water, inserted in the water sample and then reading was taken. 


\section{Temperature}

The temperature of different water samples was determined using conductivity meter (DOSJ-308A). The electrode was properly rinsed with distilled water before taking the measurement. Reading was recorded on the meter scale at a steady point.

\section{Determination of total dissolved solid (TDS)}

A clean beaker was dried at $103^{\circ} \mathrm{C}-105^{\circ} \mathrm{C}$ in an oven it was cooled in a desiccator and weighed. $100 \mathrm{ml}$ of water samples were evaporated on a water bath and dried in an oven $103^{\circ} \mathrm{C}-105^{\circ} \mathrm{C}$ in an oven for about an hour. The beaker was cooled in a desiccator, weighed again and the increase in weight was recorded as total dissolved solid.

Total dissolve solid $(\mathrm{TDS})=\frac{W_{2}-W_{1}}{100} \times 1000$

Where $\mathrm{w}_{1}=$ weight of beaker before experiment

$\mathrm{W}_{2}=$ weight of beaker after experiment

\section{Determination of total suspended solid}

$100 \mathrm{ml}$ of thoroughly mixed water sample was measuredinto a beaker, filtered with a pre-weighed Whatman filter paper (no. 42) and the residue was dried at a temperature of $103^{\circ} \mathrm{C}-105^{\circ} \mathrm{C}$ in an oven for $30-40$ minutes. Then, the filter paper and residue was cooled and weighed.

Total suspended solid $(\mathrm{TSS})=\frac{W_{2}-W_{1}}{W_{2}} \times 1000$

Where $\mathrm{W}_{1}=$ weight of filter paper

$\mathrm{W}_{2}=$ weight of filter paper + residue

\section{Determination of alkalinity}

I. Phenolphthalein alkalinity (PAK): $50 \mathrm{ml}$ of each water sample was measured into different $250 \mathrm{ml}$ conical flasks. Three drops of the phenolphthalein indicator were added. The solution remained colorless indicating a zero PAK.

II. Methyl orange alkalinity (MOAK): To the solution mixture obtained in (I) above was added three drops of methyl orange indicator to give a yellow coloration. The mixture was titrated to end point with $0.02 \mathrm{M} \mathrm{HCl} \mathrm{until} \mathrm{the}$ yellow coloration changed to a faint yellow and subsequently to pink colour.

\section{Determination of acidity}

I. Phenolphthalein acidity (PA): $50 \mathrm{ml}$ of each water sample was measured into $250 \mathrm{ml}$ conical flasks. Three drops of phenolphthalein indicator was added in each case and the solution titrated with $0.02 \mathrm{M} \mathrm{NaOH}$ until a faint pink colour was observed. This indicated the end point of the titration. 
II. Methyl orange acidity (MOA): three drops of methyl orange indicator was added and the solution titrated with $0.02 \mathrm{M} \mathrm{NaOH}$ solution to the end point.

\section{Determination of Dissolved oxygen(DO)}

The water sample was filled into a $100 \mathrm{ml}$ brown bottle; $2 \mathrm{~cm}^{3}$ of $\mathrm{MnCl}_{2}$ was added followed by $2 \mathrm{~cm}^{3}$ of potassium-iodide reagent just below the surface of the liquid. A precipitate was formed and was allowed to settle until a clear supernatant was observed. $2 \mathrm{~cm}^{3}$ of $\mathrm{HCl}$ was added to the liquid by allowing the acid to run down the neck of the bottle; this was stoppered, mixed by gentle inversion until dissolution is completed. $100 \mathrm{ml}$ of the solution was titrated against standard $0.0125 \mathrm{M}$ sodium thiosulphate $\left(\mathrm{Na}_{2} \mathrm{~S}_{2} \mathrm{O}_{3}\right)$ to give a pale yellow colour. There after, 2 drops of starch indicator was added to give a blue colour and titration continued by adding the thiosulphate solution dropwise until the blue black colour disappeared.

\section{Biochemical Oxygen Demand (BOD)}

The method for the determination of BOD was similar to that of DO. $100 \mathrm{ml}$ each water samples were collected in two brown glass stoppered bottles and labeled $\mathrm{DO}_{1}$ and $\mathrm{DO}_{2}$, then the bottles were carefully filled without trapping air bubbles. For the $\mathrm{DO}_{1}$ samples, $2 \mathrm{ml}$ of $\mathrm{MnCl}_{2}$ solution was added followed by the addition of $2 \mathrm{ml}$ potassium iodide reagent well below the surface of the liquid (water) using separate dropping pipettes. The excess solution was allowed to overflow the bottle, stoppered with care to exclude air bubbles and mixed by inverting the bottles a number of times until clear supernatant water was obtained and precipitate allowed to settle. Water samples for $\mathrm{DO}_{2}$ samples were kept in an incubator in the dark at $20^{\circ} \mathrm{C}$ for 5days. After incubation, the $\mathrm{DO}_{1}$ repeated

$\mathrm{BOD}(\mathrm{mg} / \mathrm{l})=\mathrm{DO}_{1}-\mathrm{DO}_{2}$

Where: $\mathrm{DO}_{1}=$ value of $\mathrm{DO}$ before incubator

$\mathrm{DO}_{2}=$ value of $\mathrm{DO}$ after incubator

\section{Conductivity}

Determination of conductivity was done using conductivity meter DOSJ- 308A, the electrode was properly rinsed with distilled water before taking the measurement. For every subsequent set of determination, the electrode was rinsed at each interval. Conductivitymeasurement was in $\mu \mathrm{s} / \mathrm{cm}$.

\section{Determination of chemical oxygen demand}

$100 \mathrm{ml}$ of each water samples was measured into different conical flasks. $5 \mathrm{ml}$ of dilute $\mathrm{H}_{2} \mathrm{SO}_{4}$ was added and the solution quickly transferred to 
a steam bath to boil. Then $15 \mathrm{ml}$ of $0.01 \mathrm{H}_{2} \mathrm{SO}_{4}$ was added followed by dropwise addition of $\mathrm{KMnO}_{4}(0.01 \mathrm{M})$ until the solution turned pink.

\section{Determination of Anions \\ Determination of chlorine}

To $100 \mathrm{ml}$ of each water sample, three drops of $5 \% \mathrm{~K}_{2} \mathrm{CrO}_{4}$ indicator were added and titrated with a standard $0.02 \mathrm{M} \mathrm{AgNO}_{3}$ until the colour changed from yellow to brick red.

Chloride ion concentration was calculated using:

Chloride ion concentration $(\mathrm{mg} / \mathrm{L})=(\mathrm{A} \times \mathrm{N} \times 35.45) \mathrm{X} 1000 /$ Vsample

Where: $\mathrm{A}=$ volume of titrant used, $\mathrm{N}$ is normality of silver nitrate $\mathrm{N}$ ), and Vsample is volume of sample used (ml).

\section{Determination of nitrate $\left(\mathrm{NO}_{3}{ }^{-}\right)$}

$10 \mathrm{ml}$ of each water sample was transferred into different $25 \mathrm{ml}$ standard flasks and $2 \mathrm{ml}$ of brucine reagent was added; then $10 \mathrm{ml}$ of concentrated $\mathrm{H}_{2} \mathrm{SO}_{4}$ was also added rapidly. It was mixed for about 30 secs and allowed to stand for 5 minutes. The flasks were set in cold water for about 5 minutes and then made up to volume with deionized water. The absorbance was read at $470 \mathrm{~nm}$ with optima $\mathrm{Sp}-300$ spectrometer.

\section{Determination of phosphate $\left(\mathrm{PO}_{4}{ }^{3-}\right)$}

$25 \mathrm{ml}$ of each water sample was measured into $50 \mathrm{ml}$ volumetric flasks. $10 \mathrm{ml}$ of vanadate molybdate reagent was added and diluted to volume with deionized water. A reagent blank was prepared by making up to $20 \mathrm{ml}$ mark in a $50 \mathrm{ml}$ volumetric flask. The solutions were mixed and allowed to stand for about 10 minutes for colour development. The absorbance was read at 470 nm with (optima $\mathrm{Sp}$-300) spectrometer.

\section{Determination of sulphate $\left(\mathrm{SO}_{4}{ }^{2-}\right)$}

$10 \mathrm{ml}$ of each sample was measured into different $25 \mathrm{ml}$ volumetric flasks and $10 \mathrm{ml}$ of deionized water was added. Then, $1 \mathrm{ml}$ of gelatin $\mathrm{BaCl}_{2}$ reagent was added in each case and mixed thoroughly, made up to volume with deionized water. It was allowed to stand for about 30 minutes. The absorbance was read at $420 \mathrm{~nm}$ with (optima Sp -300) spectrometer.

\section{Determination of heavy metals.}

Atomic absorption spectrometer AAS were used in the determination of the concentration of metals in all the samples. Determination of lead $(\mathrm{Pb})$, Nickel (Ni), Cadmium (Cd), Iron (Fe) andwere carried out by direct aspiration of the water samples into the air acetylene flame. Calibration curve of the metal was prepared using aliquots from standard stock solutions of the metal. 
From the calibration curves, the concentration of the metals in each water sample was determined.

Methods of data analysis

Microsoft Excel software was used to compute the mean and standard deviation. Data between the nine locations were compared with the WHO water quality standards (WHO, 2011) and the results of the samples analyses are presented in Table 1 and 2.

\section{Results and Discussion}

The results of the physicochemical analyses of water samples from Urua Ekpa, Akon Itam,Nung Ukot Itam,Ikot Atang, Oron Road, Obio Offot, Ekpri Nsukara, Ikot Akpanabia and Mbikpong community were obtained and presented in Table $1-2$.

Akwa Ibom is one of the states in Nigeria that has made considerable progress in provision of safe and potable water. This study observed that a few households in Ikot Atang, Akon Itam, Nung Ukot Itam Oron road, Obio Offot, Ekpri Nsukara, Mbikpong, Ikot Akpanabia and Urua Ekpa community obtain potable water from nearby boreholes. The characteristic of each water sample varies from one sample point to the other, which indicates the difference in the water quality in these areas.The various quality parameter values were compared with WHO recommended guidelines to determine the suitability and effect of continual consumption of such water. A summary of results on spatial variations in $\mathrm{pH}$, Temperature, Conductivity, Total dissolved oxygen, salinity, BOD, DO, COD, Alkalinity, Acidity, Total suspended solid, $\mathrm{Cl}^{-}, \mathrm{NO}_{3}{ }^{-}$ , $\mathrm{PO}_{4}{ }^{3-}, \mathrm{SO}_{4}{ }^{2-}, \mathrm{Fe}^{2+}, \mathrm{Cd}^{2+}, \mathrm{Pb}^{2+}, \mathrm{Ni}^{2+}$ and $\mathrm{Mg}^{2+}$, in the water samples are presented in Tables 1 and 2. Since the water samples are mainly used for domestic purpose, the results are discussed and compared with World Health Organization (WHO) standard for domestic drinking water.

\section{Physicochemical properties}

$\mathrm{pH}$ is important for determining the quality of drinking water. It indicates the balance between the acids and bases in water and is a measure of hydrogen ion concentration. $\mathrm{pH}$ value of 7 indicates a neutral condition, less than 7 impliesacidity and greater than 7 indicates alkalinity. Table 1 reveals that the $\mathrm{pH}$ of water in the nine (9) sampling sites ranged from $5.9 \pm 0.001$ to $6.8 \pm 0.002$, which were within the WHO limits (Table 3 ). The range of $\mathrm{pH}$ of the water in this study shows that the water is slightly acidic. Water with acidic $\mathrm{pH}$ levels can corrode plumbing and leach metal. Furthermore, iron, manganese, copper, lead, and zinc are commonly found in acidic water. Children are at greater risk because their rapidly growing bodies absorb the contaminant more quickly than adult. Adedeji et al., (2010) reported pH range of 3.19-5.18 in borehole water in Uyo metropolies, Akwa Ibom state. 
Temperature is a measure of the degree of hotness or coldness of a substance and determines to a considerable extent, the trends and tendencies of changes in its quality. It can be observed in table 1 that temperatures values ranged from $26.1 \pm 0.003$ to $26.8 \pm 0.004$. The levels of temperature obtained from the selected sampling areas were within the value set by WHO as indicated in Table 3.

Conductivity in water is affected by the presence of inorganic dissolved solids such as chloride, nitrate, sulfate, and phosphate, ions or sodium, magnesium, calcium, iron, and aluminum ions. Navneet et al.,(2010), suggested that the underground drinking water quality of study area can be checked effectively by controlling conductivity of water and this may also be applied to water quality management of other study areas. The highest value of electrical conductivity in groundwater samples is $224 \mu \mathrm{S} / \mathrm{cm}$ (Table 1), obtained from Ikot Atang community and the lowest value is $21.50 \mu \mathrm{S} / \mathrm{cm}$ obtained from Akon Itam. These values are higher than the value of 10.85 and $181.60 \mu \mathrm{s} / \mathrm{cm}$ reported by Adedeji et al., (2010) for borehole water in Uyo metropolies, Akwa Ibom state.

All water from the sampled boreholes in the study area has electrical conductivity values below permissible regulatory limits of the WHO (2011) which is $500 \mu \mathrm{S} / \mathrm{cm}$. A higher conductivity value indicates that there are more chemicals dissolved in the water (Raphael et al., 2016)

The highest and lowest values of dissolved oxygen (DO) were (13.02 and 10.25) in Ikot Atang and Nung Ukot Itam respectively (Table 1). The dissolved oxygen content of water was influenced by the source, temperature of water, treatment and chemical or biological processes taking place in the distribution system.If water is too warm, DO may reduce and when there are too many bacteria or aquatic animal in the area, it results in DO depletion due to excess use.

Biochemical oxygen demand (BOD) is the amount of dissolved oxygen needed by aerobic biological organisms to break down organic material present in a given water sample at certain temperature over a specific time period. Table 1 indicates that the values of BOD for borehole water are $6.52 \pm 0.002,6.15 \pm 0.003,6.20 \pm 0.002,5.25 \pm 0.004,5.65 \pm 0.002,5.35 \pm$ $0.003,6.42 \pm 0.001,6.85 \pm 0.001$, and $6.12 \pm 0.001 \mathrm{mg} / \mathrm{l}$. However, the mean levels of BOD in most of the water collected from the various sampling sites were lower than $6.0 \mathrm{mg} / \mathrm{l}$ set by WHO standard (2011), except the water samples of Akon Itam $(6.85 \pm 0.001)$ which is higher than the permissible limits. 
Table 1: Mean levels of physico-chemical parameters of borehole water from the study area

\begin{tabular}{|c|c|c|c|c|c|c|c|c|c|}
\hline Names & BWI & BW2 & BW3 & BW4 & BW5 & BW6 & BW7 & BW8 & BW9 \\
\hline Temp $0^{\circ} \mathrm{C}$ & $\begin{array}{l}26.1 \pm \\
0.003\end{array}$ & $\begin{array}{l}26.5 \pm \\
0.002\end{array}$ & $\begin{array}{l}26.2 \pm \\
0.003\end{array}$ & $\begin{array}{l}26.1 \pm \\
0.001\end{array}$ & $\begin{array}{l}26.6 \pm \\
0.001\end{array}$ & $\begin{array}{l}26.3 \pm \\
0.002\end{array}$ & $\begin{array}{l}26.7 \pm \\
0.002\end{array}$ & $\begin{array}{l}26.6 \pm \\
0.002\end{array}$ & $\begin{array}{l}26.8 \pm \\
0.004\end{array}$ \\
\hline pH & $\begin{array}{l}6.8 \pm \\
0.000\end{array}$ & $\begin{array}{l}6.7 \pm \\
0.000\end{array}$ & $\begin{array}{l}6.2 \pm \\
0.00\end{array}$ & $\begin{array}{c}6.7 \pm \\
0.00 \mathrm{I}\end{array}$ & $\begin{array}{l}6.8 \pm \\
0.002\end{array}$ & $\begin{array}{c}6.8 \pm \\
0.001\end{array}$ & $\begin{array}{c}6.6 \pm \\
0.002\end{array}$ & $\begin{array}{c}5.9 \pm \\
0.001\end{array}$ & $\begin{array}{l}6.6 \pm \\
0.002\end{array}$ \\
\hline Conductivity us/cm & $\begin{array}{l}71.20 \pm \\
0.003\end{array}$ & $\begin{array}{c}21.50 \pm \\
0.003\end{array}$ & $\begin{array}{c}54.20 \pm \\
0.002\end{array}$ & $\begin{array}{c}64.60 \pm \\
0.002\end{array}$ & $\begin{array}{c}26.70 \pm \\
0.002\end{array}$ & $\begin{array}{c}20.50 \pm \\
0.003\end{array}$ & $\begin{array}{c}67.20 \pm \\
0.001\end{array}$ & $224.00 \pm 0.003$ & $\begin{array}{c}32.20 \pm \\
0.001\end{array}$ \\
\hline Salinity\% & $0.00 \pm 0.000$ & $\begin{array}{c}0.00 \pm \\
0.000\end{array}$ & $\begin{array}{c}0.00 \pm \\
0.00\end{array}$ & $\begin{array}{c}0.00 \pm \\
0.000\end{array}$ & $0.00 \pm 0.000$ & $0.00 \pm 0.000$ & $\begin{array}{c}0.00 \pm \\
0.000\end{array}$ & $0.00 \pm 0.000$ & $\begin{array}{c}0.00 \pm \\
0.000\end{array}$ \\
\hline $\begin{array}{c}\text { Total dissolved solid } \\
\text { (TDS)mg/l }\end{array}$ & $35.5 \pm 0.014$ & $\begin{array}{c}10.80 \pm \\
0.011 \\
\end{array}$ & $\begin{array}{c}15.60 \pm \\
0.012 \\
\end{array}$ & $\begin{array}{c}32.30 \pm \\
0.008 \\
\end{array}$ & $\begin{array}{c}127.00 \pm \\
0.012 \\
\end{array}$ & $\begin{array}{c}98.00 \pm \\
0.014 \\
\end{array}$ & $\begin{array}{c}12.14 \pm \\
0.002 \\
\end{array}$ & $14.34 \pm 0.015$ & $\begin{array}{c}16.26 \pm \\
0.005 \\
\end{array}$ \\
\hline $\begin{array}{l}\text { Dissolved oxygen } \\
\text { (DO)mg/l }\end{array}$ & $\begin{array}{c}10.46 \pm \\
0.005\end{array}$ & $\begin{array}{c}12.08 \pm \\
0.004\end{array}$ & $\begin{array}{c}13.02 \pm \\
0.003\end{array}$ & $\begin{array}{c}11.20 \pm \\
0.003\end{array}$ & $\begin{array}{c}11.84 \pm \\
0.002\end{array}$ & $\begin{array}{c}12.40 \pm \\
0.001\end{array}$ & $\begin{array}{c}11.30 \pm \\
0.002\end{array}$ & $10.25 \pm 0.002$ & $\begin{array}{c}10.32 \pm \\
0.005\end{array}$ \\
\hline $\begin{array}{l}\text { Biochemical oxygen } \\
\text { demand (BOD)mg/l }\end{array}$ & $\begin{array}{l}6.52 \pm \\
0.002 \\
\end{array}$ & $\begin{array}{l}6.15 \pm \\
0.003 \\
\end{array}$ & $\begin{array}{c}6.20 \pm 0.00 \\
2 \\
\end{array}$ & $\begin{array}{l}5.25 \pm \\
0.004 \\
\end{array}$ & $\begin{array}{l}5.65 \pm \\
0.002 \\
\end{array}$ & $\begin{array}{l}5.35 \pm \\
0.003\end{array}$ & $\begin{array}{l}6.42 \pm \\
0.001\end{array}$ & $\begin{array}{l}6.85 \pm \\
0.001\end{array}$ & $\begin{array}{l}6.12 \pm \\
0.001\end{array}$ \\
\hline $\begin{array}{c}\text { Chemical oxygen } \\
\text { COD (mg/l) } \\
\end{array}$ & $\begin{array}{c}41.32 \pm \\
0.011 \\
\end{array}$ & $\begin{array}{c}38.55 \pm \\
0.007 \\
\end{array}$ & $\begin{array}{c}40.23 \pm \\
0.012 \\
\end{array}$ & $\begin{array}{c}39.60 \pm \\
0.015 \\
\end{array}$ & $\begin{array}{c}37.85 \pm \\
0.020 \\
\end{array}$ & $\begin{array}{c}35.50 \pm \\
0.012 \\
\end{array}$ & $\begin{array}{c}41.12 \pm \\
0.007 \\
\end{array}$ & $\begin{array}{c}45.50 \pm \\
0.011 \\
\end{array}$ & $\begin{array}{c}42.16 \pm \\
0.006\end{array}$ \\
\hline $\begin{array}{c}\left.\text { Alkalinity(as } \mathrm{CaCO}_{3}\right) \\
\text { mg/l }\end{array}$ & $\begin{array}{c}88.00 \pm \\
0.009\end{array}$ & $\begin{array}{c}24.00 \pm \\
0.006\end{array}$ & $\begin{array}{c}65.00 \pm \\
0.003\end{array}$ & $\begin{array}{c}16.00 \pm \\
0.005\end{array}$ & $\begin{array}{c}24.00 \pm \\
0.006\end{array}$ & $\begin{array}{c}12.00 \pm \\
0.011 \\
\end{array}$ & $\begin{array}{c}13.00 \pm \\
0.004\end{array}$ & $\begin{array}{c}11.20 \pm \\
0.005\end{array}$ & $\begin{array}{c}16.00 \pm \\
0.003\end{array}$ \\
\hline $\begin{array}{c}\text { Acidity (as CaCO3) } \\
\text { mg/l }\end{array}$ & $\begin{array}{c}48.00 \pm \\
0.004\end{array}$ & $\begin{array}{l}112.00 \pm \\
0.003\end{array}$ & $\begin{array}{c}100.00 \pm \\
0.001\end{array}$ & $\begin{array}{l}144.0 \pm \\
0.005\end{array}$ & $\begin{array}{l}96.00 \pm \\
0.006\end{array}$ & $\begin{array}{c}105.00 \pm \\
0.003\end{array}$ & $\begin{array}{c}99.00 \pm \\
0.002\end{array}$ & $\begin{array}{c}160.00 \pm \\
0.004\end{array}$ & $\begin{array}{c}64.00 \pm \\
0.004\end{array}$ \\
\hline $\begin{array}{l}\text { Total suspended solid } \\
\text { (TSS)mg/l }\end{array}$ & $\begin{array}{c}24.00 \pm \\
0.002\end{array}$ & $\begin{array}{c}20.00 \pm \\
0.001\end{array}$ & $\begin{array}{c}22.00 \\
\pm 0.000\end{array}$ & $\begin{array}{l}36.00 \pm \\
0.003\end{array}$ & $\begin{array}{l}28.00 \pm \\
0.003\end{array}$ & $\begin{array}{c}32.00 \pm \\
0.003\end{array}$ & $\begin{array}{c}28.00 \pm \\
0.001\end{array}$ & $\begin{array}{c}26.00 \pm \\
0.002\end{array}$ & $\begin{array}{c}30.00 \pm \\
0.003\end{array}$ \\
\hline
\end{tabular}


Table 2: Heavy metal concentration from the water samples at the study areas (mg/l)

\begin{tabular}{|c|c|c|c|c|c|c|c|c|c|}
\hline Site & $\mathbf{P b}$ & Cd & $\mathbf{F e}$ & Mg & $\mathbf{N i}$ & $\mathrm{SO}_{4}{ }^{2-}$ & $\mathrm{NO}_{3}{ }^{-}$ & $\mathrm{PO}_{4}{ }^{3-}$ & $\mathrm{Cl}^{-}$ \\
\hline BW1 & $0.058 \pm 0.002$ & $0.003 \pm 0.004$ & $1.39 \pm 0.004$ & $58.66 \pm 0.012$ & $0.008 \pm 0.003$ & $14.07 \pm 0.003$ & $16.19 \pm 0.003$ & $14.86 \pm 0.005$ & $19.88 \pm 0.002$ \\
\hline BW & $0.003 \pm 0.003$ & $0.006 \pm 0.003$ & $1.44 \pm 0.003$ & $39.48 \pm 0.011$ & $0.004 \pm 0.002$ & $10.55 \pm 0.001$ & $31.58 \pm 0.005$ & $15.32 \pm 0.002$ & $11.36 \pm 0.004$ \\
\hline BW3 & $0.004 \pm 0.001$ & $0.008 \pm 0.002$ & $2.04 \pm 0.003$ & $45.52 \pm 0.012$ & $0.005 \pm 0.002$ & $11.04 \pm 0.002$ & $29.30 \pm 0.003$ & $12.32 \pm 0.001$ & $15.05 \pm 0.003$ \\
\hline BW4 & $\begin{array}{c}0.0013 \pm \\
0.002\end{array}$ & $0.0012 \pm 0.001$ & $1.54 \pm 0.002$ & $47.54 \pm 0.015$ & $0.006 \pm 0.001$ & $11.56 \pm 0.002$ & $40.89 \pm 0.005$ & $29.03 \pm 0.002$ & $14.20 \pm 0.001$ \\
\hline$\overline{\text { BW5 }}$ & $0.006 \pm 0.003$ & $0.004 \pm 0.003$ & $1.18 \pm 0.004$ & $42.54 \pm 0.015$ & $0.005 \pm 0.001$ & $14.57 \pm 0.002$ & $21.46 \pm 0.003$ & $14.26 \pm 0.003$ & $17.04 \pm 0.002$ \\
\hline BW6 & $\begin{array}{c}0.0026 \pm \\
0.002\end{array}$ & $0.005 \pm 0.002$ & $1.13 \pm 0.002$ & $39.41 \pm 0.006$ & $0.005 \pm 0.002$ & $10.53 \pm 0.001$ & $41.50 \pm 0.002$ & $20.30 \pm 0.003$ & $10.03 \pm 0.002$ \\
\hline BW7 & $0.003 \pm 0.002$ & $0.0046 \pm 0.003$ & $1.79 \pm 0.002$ & $55.12 \pm 0.012$ & $0.004 \pm 0.002$ & $13.58 \pm 0.001$ & $38.10 \pm 0.003$ & $15.30 \pm 0.001$ & $11.10 \pm 0.001$ \\
\hline BW8 & $0.003 \pm 0.003$ & $0.0026 \pm 0.002$ & $1.08 \pm 0.004$ & $63.71 \pm 0.015$ & $0.005 \pm 0.002$ & $23.62 \pm 0.004$ & $40.49 \pm 0.004$ & $15.86 \pm 0.002$ & $18.46 \pm 0.003$ \\
\hline BW9 & $0.004 \pm 0.003$ & $0.0015 \pm 0.004$ & $1.49 \pm 0.002$ & $45.16 \pm 0.012$ & $0.004 \pm 0.003$ & $15.58 \pm 0.002$ & $25.91 \pm 0.003$ & $15.59 \pm 0.001$ & $15.05 \pm 0.002$ \\
\hline
\end{tabular}

Mean \pm Standard deviation of 3 determination

Note: $\mathrm{BW}=$ Borehole water

Itu L.G.A.: BW1 = Urua Ekpa, BW2 = Akon Itam, BW3 = Nung Ukot Itam

Uyo L.G.A.: BW4 = Oron Road, Uyo, BW5 = Ekpri Nsukara, Offot ,BW6 = ObioOffot, Uyo

Ibesikpo L.G.A.: BW7 = Ikot Akpanabia, BW8 = Ikot Atang, BW9 = Mbikpong 
Table 3:Physico-chemical properties of World Health Organization WHO (2011) standards for drinking.

\begin{tabular}{|c|c|c|c|c|c|c|c|c|c|c|c|}
\hline $\begin{array}{c}\text { Param } \\
\text { eters }\end{array}$ & $\begin{array}{c}\text { Temp } \\
\left({ }^{\circ} \mathrm{C}\right)\end{array}$ & $\mathrm{pH}$ & $\begin{array}{c}\text { Salin } \\
\text { ity }\end{array}$ & $\begin{array}{c}\text { TDS } \\
(\mathrm{mg} / \mathrm{l})\end{array}$ & $\begin{array}{c}\text { BOD } \\
(\mathrm{mg} / \mathrm{l})\end{array}$ & $\begin{array}{c}\text { DO } \\
(\mathrm{mg} / \mathrm{l})\end{array}$ & $\begin{array}{c}\text { COD } \\
(\mathrm{mg} / \mathrm{l})\end{array}$ & $\begin{array}{c}\text { Alkalinity } \\
(\mathrm{mg} /)\end{array}$ & $\begin{array}{c}\text { Acidity } \\
(\mathrm{mg} / \mathrm{l})\end{array}$ & $\begin{array}{c}\text { EC } \\
(\mu \mathrm{s} / \mathrm{cm})\end{array}$ & $\begin{array}{c}\text { TSS } \\
(\mathrm{mg} / \mathrm{l})\end{array}$ \\
\hline WHO & 25 & $\begin{array}{c}6.5- \\
8.5\end{array}$ & - & 600 & 6 & - & 10 & & & 1000 & \\
\hline
\end{tabular}

Table 4: Elemental composition of World Health Organization WHO (2011) guidelines for drinking water.

\begin{tabular}{|l|l|l|l|l|l|l|l|l|l|}
\hline Parameters & $\mathbf{P b}$ & $\mathbf{C d}$ & $\mathbf{F e}$ & $\mathbf{M g}$ & $\mathbf{N i}$ & $\mathbf{S O}_{4}^{2-}$ & $\mathbf{N O}_{3}^{-}$ & $\mathbf{P O}^{\mathbf{3}}$ & $\mathbf{C l}^{-}$ \\
\hline $\begin{array}{l}\text { WHO } \\
(\mathrm{mg} / \mathrm{l})\end{array}$ & 0.01 & 0.01 & 0.3 & 50 & 0.01 & 250 & 100 & 250 & 250 \\
\hline
\end{tabular}

Chemical oxygen demand (COD) is the amount of dissolved oxygen required to cause chemical oxidation of the organic material in water, it is a water quality measure used not only to measure the amount of biologically active substances such as bacteria but also biologically inactive organic matter in water. The values obtained for COD from borehole water ranges from 37.85 $\pm 0.020-45.50 \pm 0.011$ (Table 1). The mean levels of COD in the water collected from the various sampling sites exceed the WHO guideline value of $10 \mathrm{mg} / \mathrm{l}$ (Table 3). It is observed that the water samples of Ikot Atang is 45.50 \pm 0.011 and is the highest compared to other water samples.

Alkalinity is a measure of the capacity of water to neutralize acids. The predominant chemicals present in natural waters are carbonates, bicarbonates, and hydroxides. The total Alkalinity values ranged from $11.20 \pm 0.005 \mathrm{mg} / \mathrm{l}-$ $88.00 \pm 0.009 \mathrm{mg} / \mathrm{l}$ for all the water samples shown in table 1. High concentrations of alkalinity leads to corrosion and influences chemical and biochemical reactions.

Total dissolved solid is index of the amount of dissolved substances in the water. The values obtained from the sampling sites $10.80 \pm 0.011$ $127.00 \pm 0.012$ (Table 1). The levels of total dissolved solid in water obtained from the sample sites were lower than the value for the WHO (2011), which is $1000 \mathrm{mg} / \mathrm{l}$, except site BW5. High concentrations of TDS in water samples affect deteriorate plumbing and appliances. The relative high TDS could be as a result of direct discharge of chemicals, domestic waste waters, run-off from roads and dumpsites as well as water from benefication of minerals sites leakage into underground water, increased levels of TDS can give water a bitter, metallic, or salty taste, along with discolouring the water and an unpleasant odour.

In this study, the possible cause of low concentration of TDS was the minimal presence of these chemicals in the ground water. The WHO permissible limit for TDS is $500 \mathrm{mg} / \mathrm{l}$ for potable drinking water (WHO, 2011). 
Thus, from results obtained the groundwater samples are potable with respect to TDS.

\section{Anions concentrations}

Table 2 shows that the chloride content in the water samples varied from $10.03 \pm 0.002-19.88 \pm 0.002$. Chloride $\left(\mathrm{Cl}^{-}\right)$concentration for all water samples was less than $250 \mathrm{mg} / 1$ limit set by WHO (Table 4). Adedeji et al., (2010) also repoted the chloride values less than $250 \mathrm{mg} / \mathrm{l}$ for borehole water in Uyo metropolies, Akwa Ibom state. Values above $250 \mathrm{mg} / \mathrm{l}$ for chloride will impart unpleasant odourto water, especially sodium salts and could be toxic when the concentration is high.

Nitrates are widely present in substantial quantities in soils and in most water. Nitrates are products of oxidation of organic nitrogen by bacteria present in the soils and in the water where sufficient oxygen is present. Values obtained from the study area were $16.19 \pm 0.003,31.58 \pm 0.005,40.89 \pm 0.005$, $21.46 \pm 0.003,40.49 \pm 0.004$, and $25.91 \pm 0.003 \mathrm{mg} / 1$ (Table 2). These values are high, though not exceed the values set by WHO (2006). The values of 0.5 - 4.9 was reported by Adedeji et al., (2010) for borehole water in Uyo metropolies, Akwa Ibom state. Nitrate is not especially dangerous but certain bacteria sometime present in digestive tract convert nitrates into nitrites, which are highly toxic. It has been recommended that water supplies containing high levels of nitrate $(100 \mathrm{mg} / \mathrm{l})$ should not be used for preparation of infant foods.

Phosphorus is one of the key elements necessary for the growth of plants and animals. Phosphorus in elemental form is very toxic and is subjected to bioaccumulation. Phosphate $\left(\mathrm{PO}_{4}{ }^{3-}\right)$ is formed from Phosphorus. The mean phosphate values recorded for all the sampling sites were generally lower compared with WHO (2006) guideline value of $250 \mathrm{mg} / \mathrm{l}$, hence it may not be toxic to people or animal. Digestive problems could occur from extremely high levels of phosphates.

Most of the metallic sulphates are soluble in water which implies possible leaching of sulphate from the top soil to the surface water, and underground water. The values of sulphates obtained ranged from $10.55 \pm$ $0.001-23.62 \pm 0.004$ as shown in Table 2 The result obtained for borehole water samples in the study areas is below the permissible range $(250 \mathrm{mg} / \mathrm{l})$ based on WHO standard (2011).

\section{Cations concentrations}

Iron in concentrations greater than $0.3 \mathrm{mg} / \mathrm{l}$ may cause black and brown stains on laundry, plumbing, fixtures and sinks. A man requires between 2 and $3 \mathrm{mg} / \mathrm{l}$ of iron per day and $60 \%$ to $70 \%$ of ingested amount are metabolized. Iron contentvalue obtained in borehole water samples were between $1.08 \pm$ 0.004 , and $1.54 \pm 0.002 \mathrm{mg} / 1$ which exceed the value set by WHO (2011). 
However, the high concentration of iron does not appear to present health hazard butit may affect the taste of beverages made from the water. This situation can be remedied by adding water softener or iron filter.

For the lead concentrations the analyzed values with the mean ranged from $0.002 \pm 0.003-0.005 \pm 0.002 \mathrm{mg} / \mathrm{l}$ (Table 2), which are lower than the WHO permissible value of $0.01 \mathrm{mg} / \mathrm{l}$ (Table 4); therefore, the water is fit for consumption as it will pose no heath problem. High concentration of lead in water samples leads to delay in physical and mental development especially of infant and children.

Nickel concentrations in the water samples ranged from $0.004 \pm 0.003$ to $0.008 \pm 0.002 \mathrm{mg} / \mathrm{l}$ with the none of the samples recording a higher value than the WHO guideline value of $0.01 \mathrm{mg} / \mathrm{l}$ (Table 4). Generally, the nickel amount in the water samples within the study area is not hazardous to the health. High Nickel content in water may lead to cancer of the lungs, nose, bone and dermatitis

The cadmium concentration in the water samples ranged from of 0.001 $\pm 0.004-0.008 \pm 004 \mathrm{mg} / \mathrm{l}$ (Table 2), which were all lower than the WHO permissible limitof $0.01 \mathrm{mg} / \mathrm{l}$ (Table 4). Therefore, the level of cadmium in the water samples in all the study areas are not toxic to human health. High cadmium concentration in water usually causes kidney damage to human.

The concentrations of magnesium in all nine (9) water samples varied from 39.41 to $63.71 \mathrm{mg} / \mathrm{l}$, as indicated in Table 2 . With the exception of BW $1(58.66 \mathrm{mg} / \mathrm{l})$, BW $7(55.12 \mathrm{mg} / \mathrm{l})$ and BW $8(63.71 \mathrm{mg} / \mathrm{l})$, the magnesium content were below the WHO tolerance limits of $50 \mathrm{mg} / \mathrm{l}$ (Table 4). Presence of $\mathrm{Mg}$ in water samples is an indication of eroded rocks and minerals such as limestone, dolomite, calcite and magnetite into the water bed, which renders the water hard and unfit for human consumption.

\section{Conclusion:}

In conclusion, the underground water from the nine sample areas posess variable physicochemical properties. Based on the results, the cations and anions analyzed in the water samples were found to be within WHO acceptable standard for drinking water, iron which exceeded the permissible limits. Most of the observed heavy metals and anions levels in the analyzed ground water are generally suspected to originate from anthropogenic activities.The physico-chemical parameters and heavy metals concentration in these sampling sites should be monitored regularly and there is need to create awareness among the populace on the dangers of heavy metals pollution. 


\section{References:}

1. Adedeji, A., Babatunde, A., and Aderemi, A. (2010). Hydrochemical investigation of Groundwater quality in selected locations in Uyo, Akwa Ibom state of Nigeria. New York Science Journal, 117 - 122

2. Arjun Chandra Bhowmick, M. Abdur Rahaman, Merazul Islam, Nishat Akther, M. Shahadat Hossain, M. A. Majed Patwary. (2015). Comparative adsorption study on rice husk and rice husk ash by using amaranthus gangeticus pigments as dye European Scientific Journal, 11(21) :254- 265

3. Bashir, A. and Olalekan, A.(2012). Assessment of borehole water quality in Yola-Jimeta Metropolis,Nigeria. International Journal of Water Resources and Environmental Engineering,4(9):287-293

4. Ebrahim Alwashali, Boubker Jghalef, Mohamed Fadli, Chakir Ashraf, Guemimi Abdelhak(2014) Assessment of microbial contamination of groundwater in oualidia area, morocco. European Scientific Journal, 10(14): $71-84$

5. Gloria N. W., and Token L.J. (2015). Physicochemical Quality of Borehole Water in Abonnema and Its Public Health Importance.Global Journal of Pure and Applied Sciences, 21: 97-104

6. Goel, P.K. (1995). Water Pollution: Causes, Effects and Control. New Age International limited, Publishers, New Delhi, 11002.

7. Istifanus, Y. C., Elisha, K., Ishaku, Z. and Ephraim D. A. (2013). Physicochemical Analysis of Ground Water of Selected Areas of Dass and Ganjuwa Local Government Areas, Bauchi State, Nigeria.World Journal of Analytical Chemistry,4:73-79

8. Jacob. A. and Peter. U. U.(2015). Dimension in Rural Coverage and Access in AkwaIbom State, Nigeria. African Journal of Environmental Science and Technology. 9(1):29-37.

9. Khitoliya, R.K. (2004). Environmental Pollution: Management and Control for Sustainable Development. S. Chand, 44-45

10. Madden, B. (1995).Cleanup of contaminated acquirers. GSI 150th Anniversary Environmental Geology Symposium

11. Meador, F., Maharahel, F. and Ahmadi, F. (1995).Simultaneous Preconcentration and Determination of Copper, Cobalt and Lead ions.Fresher Environmental Bulletin, 14:1158-1165.

12. National Population Census (2007). Result. Legal Notice on the Details of the Breakdown of the National and State Provisional Total. National Population Commission. Printed and published by the Federal Government Printer, Lagos, Nigeria.

13. Navneet, K. and Sinha D. K.. (2010).Drinking water quality management through correlation studies among various 
physicochemical parameters: A case study, International Journal of Environmental Sciences, 1(2):253-259.

14. Pawari, M. J. and Gawande S. (2015). Ground water pollution and its consequence.InternationalJournal of Engineering Research any General Science, 3 (4):773-76.

15. Raphael, C. M., Russel, C.G. and Elijah M.M. (2016).Assessment of drinking water quality and rural household water treatment in Balaka District. Physics and Chemistry of the Earth. 100: 353-362

16. World Health Organization (WHO), (2011). Guidelines for drinkingwater quality

17. WHO (2006). Guidelines for drinking water quality.2nd edition.Recommendation, World Health organization Geneva. 1:3031 